\title{
THE EFFECTS OF ENDURANCE TRAINING AND ESTROGEN-RELATED RECEPTOR $\alpha$ DISRUPTION ON MITOFUSIN 1 AND 2, GLUT2, PPARß/ס AND SCD1 EXPRESSION IN THE LIVER OF DIABETIC RATS
}

\author{
B. SHAHOUZEHI ${ }^{1,2}$, Y. MASOUMI-ARDAKANI ${ }^{3}$, H. FALLAH ${ }^{4}$, S. AMINIZADEH ${ }^{3 凶}$ \\ ${ }^{1}$ Student Research Committee, School of Medicine, Kerman University \\ of Medical Sciences, Kerman, Iran; \\ ${ }^{2}$ Cardiovascular Research Center, Institute of Basic and Clinical Physiology \\ Sciences, Kerman University of Medical Sciences, Kerman, Iran; \\ ${ }^{3}$ Physiology Research Center, Institute of Basic and Clinical Physiology \\ Sciences, Kerman University of Medical Sciences, Kerman, Iran; \\ ${ }^{4}$ Department of Biochemistry, Afzalipour School of Medicine, \\ Kerman University of Medical Sciences, Kerman, Iran; \\ ${ }_{e}$-mail: soheilaminizadeh@gmail.com
}

Received: 19 March 2020; Accepted: 13 November 2020

Diabetes is a progressive and metabolic disease with a high prevalence throughout the world. Physical activity is considered as an intervention to improve diabetes. Intervention such as estrogen-related receptor $\alpha$ (ERR $\alpha$ ) inhibition is considered as a new way to manage diabetes. In current study, we examined ERR inhibition along with exercise training (ET) on the gene expression of mitofusin 1 (MFN1), MFN2,

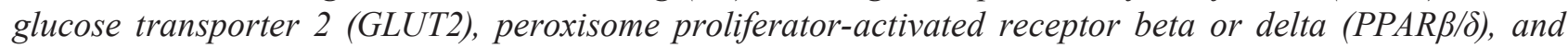
stearoyl-CoA desaturase 1 (SCD1) in rat liver. The animals were divided into 8 groups $(n=7)$; 1 , Control (CTL) 2, Diabetes (D) 3, ERR inhibition (ERRI) 4, Endurance Training (ET) 5, Diabetes + ERR $\alpha$ inhibition (D+ERRI) 6, Diabetes + Endurance training $(D+E T)$ 7, Endurance Training $+E R R \alpha$ inhibition (ET+ERRI) 8, Diabetes + Endurance Training $+E R R \alpha$ inhibition $(D+E T+E R R I)$. The liver tissues were used for Real-Time $P C R$. The results showed that ET significantly increased PPAR $\delta$, MFN1 and, MFN2 expression in control rats compared to D group. In ERRI group, SCD1, GLUT2, MFN1 and MFN2 gene expression was increased compared to CTL and DM group. In CTL and D rats, the combination of ERR inhibition and ET significantly and additively increased MFN1, MFN2, and GLUT2 expression. Overall, the combination of ET and ERR $\alpha$ inhibition probably can be considered as a potential therapeutic intervention for treatment of metabolic diseases including diabetes and cardiovascular disease.

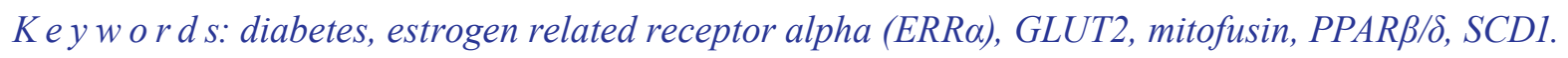

$\mathrm{D}$ espite available medications and managements, diabetes is still a widespread metabolic disease characterized by insulin secretion and function defects and hyperglycemia. Diabetes prevalence is increasing and estimated to affects about $5.4 \%$ of the world population by 2025 . Therefore, promising and valuable management is needed to reduce diabetes and its complications. The attention on exercise and physical activity to reduce diabetes complications was increased [1].
Endurance training (ET) described as an aerobic training that is a good alternative for diabetic patients. ET showed beneficial effects on diabetes such as reduced hyperglycemia, improved lipid profile, decrease body weight, and increase insulin sensitivity and mitochondrial size and contents [2-4]. Therefore, much attention has been paid to the beneficial effects of exercise on the prevention and treatment of diabetes [5, 6].

(C) 2020 Shahouzehi B. et al. This is an open-access article distributed under the terms of the Creative Commons Attribution License, which permits unrestricted use, distribution, and reproduction in any medium, provided the original author and source are credited. 
The dynamic of mitochondria is maintained by a balance between fusion and division [7]. Disturbed mitochondrial dynamic and function are related to diabetes and insulin resistance pathogenesis [4]. It has been described that Mitofusin (MFN) proteins modulates mitochondria dynamic and biogenesis. MFN1 and MFN2 were up-regulated by exercise training, and this elevation was mediated by Peroxisome proliferator-activated receptor gamma coactivator 1- $\alpha /$ Estrogen-related receptor $\alpha$ (PGC$1 \alpha / E R R \alpha)$. Also, it has been shown that MFN2 inactivation results in mitochondrial dysfunction and defect in mitochondrial fusion that reduces mitochondrial oxidative capacity [4].

The estrogen-related receptors (ERRs) are important for regulation of cellular energy metabolism $[8,9]$. ERR $\alpha$ expressed in a tissue specific manner and expressed in tissues with high oxidative metabolism demands such as skeletal muscle, adipose tissue, and liver where it affects carbohydrate and lipid metabolism, and mitochondrial activity. ERR $\alpha$ inhibition is related to reduce body weight and $E R R \alpha^{-/-}$ mice showed reduced serum glucose and improved insulin sensitivity [9].

Unlike adipose tissue and skeletal muscles, the transport of glucose into hepatocytes is not a ratelimiting step. In fact, transport of glucose into the adipose tissue and skeletal muscles is an insulindependent process, but in hepatocytes, this transportation is not insulin-dependent. This transportation process conducted through the membrane facilitated-diffusion glucose transporters family that their distribution is tissue-specific. Glucose transporter 2 (GLUT2) is mainly expressed in the liver and on the other hand, GLUT4 is mainly expressed in adipose tissue and skeletal muscle [10]. The expression of GLUT2 in the liver is reduced by insulin and increased by glucose level. Also, it was reported that GLUT2 is acting as a glucose sensor in the liver [11]. The data reported over the GLUT2 expression in the liver of diabetic models are controversial [1016]. It has been described that GLUT2 expression was increased in diabetic rats and this elevation was reduced to normal by insulin therapy [10]. Also, GLUT2 gene and protein expression decreased in diabetic mice and rats, and this reduction was related to glucose-stimulated insulin secretion [11, 12]. Rathinam and Pari (2016) reported that liver GLUT2 expression was reduced in STZ-induced diabetic rats [13]. Sandoval-Muníz et al have found that gene expression of GLUT2 was increased after diabetes induction by STZ compared to control group [14]. Also, Jurysta et al showed that GLUT2 expression was up-regulated in the liver and lung [16].

Mitochondria have a vital role in energy metabolism and its defects are connected to liver dysfunction. There are proteins that involved in the mitochondrial dynamic network including MFN1, MFN2, optic atrophy 1 (OPA1) and dynamin-related protein (DRP1) [17]. Mitochondrial dynamic is dependent on the balance between fusion or fission and precise functioning of mitochondrial biogenesis. It was suggested that the possible imbalance in those processes is connected to metabolic disease [18]. MFN1 and MFN2 showed high similarity (about $60 \%$ ) and are involved in mitochondrial fusion. But it was revealed that MFN2 has other functions, for example, the connection between MFN2 and cellular metabolism was described in diabetes $[18,19]$. Reduced rat liver MFN2 activity was related to the metabolic disorders such as diabetes, decreased glucose oxidation, and tricarboxylic acid (TCA) cycle activity [18]. Also, it was confirmed by Soriano and colleague (2006) that MFN2 expression in diabetes was reduced [19]. It has been reported that ERR $\alpha$ up-regulated MFN2 gene expression. This was documented that improved insulin sensitivity after exercise was related to MFN2 up-regulation [19]. PGC-1 $\alpha /$ ERR $\alpha$ exerts their role in mitochondrial fusion thorough MFN2 elevation [4]. Exercise is considered as an important factor that decreased mitochondrial imbalance [20]. Koo and Kong found that exercise on treadmill increased fusion proteins such as OPA1, MFN1 and MFN2 in the brain [20].

PPARs are transcriptional factors belong to the nuclear hormone receptor superfamily. There are three isotypes of PPAR family designated as $\operatorname{PPAR} \alpha, \operatorname{PPAR} \beta / \delta$, and PPAR $\gamma$ [21]. They control various gene expression involved in carbohydrate/ lipid metabolism, cell differentiation and proliferation. PPAR $\delta$ regulates cellular energy homeostasis and involved in Fatty acid oxidation (FAO), mitochondrial oxidative phosphorylation and FA transport $[21,22]$. PPAR $\delta$ affects liver and peripheral tissue energy consumption and therefore attenuates insulin resistance. PPAR $\delta$ increases insulin secretion and glucose homeostasis, and influenced FAO. These PPAR $\delta$ functions proved its protective effects against insulin resistance, obesity, hepatosteatosis, diabetes and atherosclerosis [22, 23]. Cheng et al have reported that exercise beneficial effects on vascular functions mediated thorough PPAR $\delta$ [24]. Changes 
in substrate consumption from carbohydrates toward lipids are a marker of training. Fan and colleagues (2017) showed that PPAR $\delta$ is related to ET in mice and PPAR $\delta$ up-regulation significantly reduced glucose oxidation [25].

Stearoyl CoA Desaturase 1 (SCD1) is involved in monounsaturated FAs synthesis that controls this process. SCD1 is also important for TG production and storage. SCD activity increased in diabetes and is correlated with obesity and cardiovascular disease (CVD) [26]. Shen et al reported that SCD1 expression was increased after high far diet but not by exercise training [27]. Yasari and coworkers (2010) reported that 8-week exercise program remarkably down-regulated hepatic SCD1 protein and gene expression [28]. A single bout of ET raised SCD index [29]. It has been documented that SCD1 is necessary for triggering diet-induced insulin resistance at the liver level [30, 31].

ERR $\alpha$ regulates energy metabolism and affects fuel expenditure. Beneficial effects of ET on metabolism in diabetes were confirmed. In this study, we examined the expression of genes involved in mitochondrial fusion (MFN1 and MFN2), and GLUT2 that sensing glucose in the liver, and other genes that regulate lipid metabolism (PPAR $\delta$ and SCD1 expression) in the liver of non-diabetic and diabetic rats that performed ET. ERR $\alpha$ was inhibited and a combination of both (ET+ERR $\alpha$ inhibition) to evaluate ERR $\alpha$ inhibition effects on genes involved in metabolism and mitochondrial dynamic in diabetic models along with ET.

\section{Materials and Methods:}

Materials. XCT790 (Sigma, X4753), STZ (Sigma, No: S0130), Total RNA isolation kit (Bio Basic; BS414), cDNA synthesis kit (TAKARA; RR037A), SYBR Green (Ampliqon; A325402).

Study groups. All the animal procedures were in accordance with the requirements of the European Convention for the protection of vertebrate animals used for experimental and other scientific purposes. This study was approved by the ethics committee of the Kerman Medical University Research Council (No. IR.KMU.REC13970321). In this study, we used 56 male Wistar rats in 8 groups (weight, $190 \pm 15 \mathrm{~g}$ ). The animals were maintained at controlled condition, $24 \pm 2^{\circ} \mathrm{C}, 12 / 12 \mathrm{~h}$ light/dark cycle, and free access to chow diet and water. After acclimatization with new condition, the animals were randomly divided into 8 groups that were as follows; 1 , Con- trol (CTL) 2, Diabetes Mellitus (DM; STZ-induced diabetic that received an i.p. dose of STZ $(45 \mathrm{mg} /$ kg)) 3, ERR $\alpha$ inhibition (ERRI; received daily i.p. injection of $0.48 \mathrm{mg} / \mathrm{kg}$ of XCT790) 4, Endurance Training (ET) 5, Diabetes Mellitus+ERR $\alpha$ inhibition (DM+ERRI) 6, Diabetes Mellitus+Endurance training (DM+ET) 7, ERR inhibition+Enduranc Training (ERRI+ET) 8, Diabetes Mellitus+Endurance Training+ERR $\alpha$ inhibition (DM+ET+ERRI). The duration of the study was 4 weeks and at the end of the study, animals were sacrificed and abdominal part was incised and liver was dissected and washed with cold saline and finally freeze by liquid nitrogen. The obtained liver tissues were stored at -80 until future measurements [32].

Diabetes induction. The experimental diabetes was induced before ET and by a single dose of i.p. injection of STZ $(45 \mathrm{mg} / \mathrm{kg}$ prepared in $0.1 \mathrm{M}$ citrate buffer, $\mathrm{pH} 4.5$ ) in rats that were fasted overnight. Three days after STZ injection fasting blood glucose (FBG) in overnight fasted animals was measured by glucometer (Accu-Check, Germany) to confirm diabetes induction. Animals with FBG higher than $250 \mathrm{mg} / \mathrm{dl}$ were confirmed as diabetic models and randomly entered into diabetic groups of the study.

Endurance training (ET) protocol. Animals performed ET for 4 weeks (5 days per week). The groups that have to carry out training were familiarized with training protocol on a treadmill at lowspeed (15-20 m/min) for a week. Then, the duration was gradually raised for 4 weeks. In the last two weeks, rats trained $50 \mathrm{~min}$ daily $(27 \mathrm{~m} / \mathrm{min})(13 \mathrm{p} . \mathrm{m}$ for about $5 \mathrm{~h}$ ) [33].

ERR $\alpha$ inhibition. This was indicated that ERR $\alpha$ can be inhibited by the thiadiazole acrylamide (XCT790- $\mathrm{C}_{23} \mathrm{H}_{13} \mathrm{~F}_{9} \mathrm{~N}_{4} \mathrm{O}_{3} \mathrm{~S}$ ). Therefore, in this study we inhibited ERR $\alpha$ by daily XCT790 $(0.48 \mathrm{mg} / \mathrm{kg})$ intraperitoneal injections for 28 days (Diagram) (7:30 a.m for about $30 \mathrm{~min}$ ) [8, 32].

Total RNA extraction, cDNA synthesis and Real-time PCR. We used $50 \mathrm{mg}$ of the liver for total RNA extraction. The liver tissue was homogenized at lysis buffer by Sonicator (Heilscher H200, Germany), total RNA was extracted by the EZ-10 Spin Column according to Bio Basic kit's protocol. Next, the cDNA was synthesized from extracted total RNA (600 ng) by TAKARA cDNA synthesis kit. We used gene-specific primers for Real-time PCR which purchased from metabion international (metabion GmbH, Germany) (Table). Each Real-time PCR reaction contained $10 \mu \mathrm{l}$ Ampliqon SYBR green, 


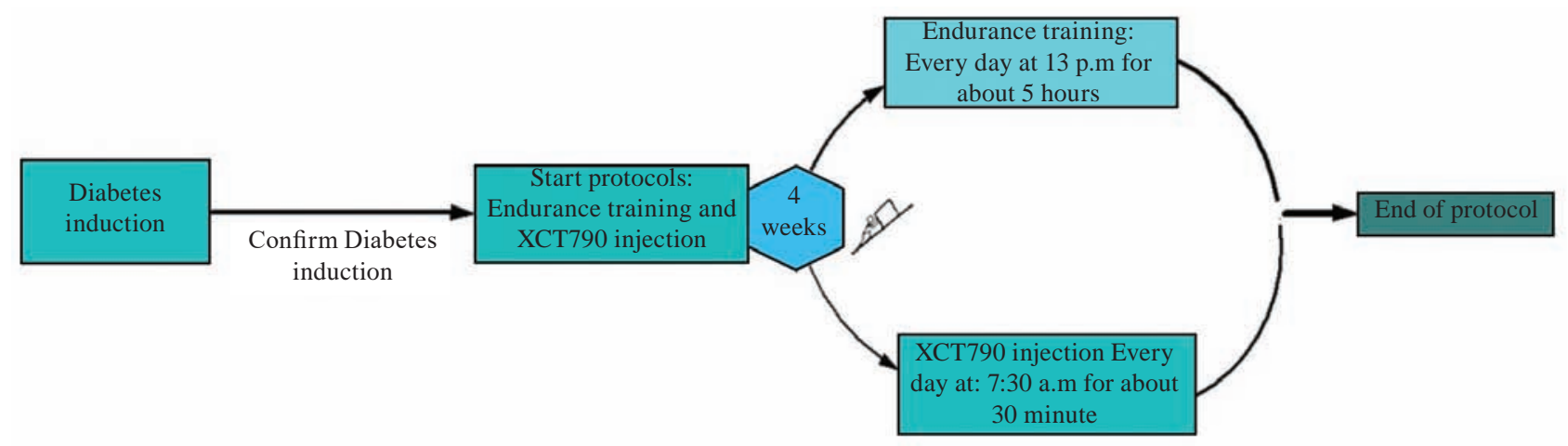

Diagram. Protocols and time points

forward and reverse primers ( $1 \mu$ from each one), $100 \mathrm{ng}$ of previously synthesized cDNA, and reaction volume reached to $20 \mu \mathrm{l}$ by distilled water. The annealing temperature for each primer was adjusted according to its $\mathrm{Tm}$. The thermal procedure was as follow; $95^{\circ} \mathrm{C}$ ( $\left.5 \mathrm{~min}\right), 95^{\circ} \mathrm{C}$ (15 sec), annealing temperature ( $45 \mathrm{sec}$ ), 40 cycles. At the end of the Realtime PCR runs we defined the melt curve analysis. The 18S rRNA was used as a housekeeping and control gene and the relative expression of genes was determined by $2^{-\Delta \Delta \mathrm{Ct}}$ method [34].

Statistical analysis. The analysis in this study was performed by SPSS version 22 and Sigma Plot version 12 . The data were analyzed by two-way analysis of variance (Two-Way ANOVA) test and to pairwise comparisons; Tukey's method was used. Data are expressed as Mean \pm SEM. The $P$ values $<0.05$ were considered significant.

\section{Results and Discussion}

The combination of ERR $\alpha$ inhibition and ET in non-diabetic rats significantly increased MFN1 expression compared to non-diabetic control, ET, and non-diabetic rat with ERR $\alpha$ inhibition $(P<0.001)$. The combination of ERR $\alpha$ inhibition and ET in diabetic rats, significantly increased MFN1 expression compared to diabetic control, diabetic rats performed ET $(P<0.001)$, and diabetic rats with ERR $\alpha$ inhibition $(P=0.002)$ (Fig. 1).

The combination of ERR $\alpha$ inhibition+ET in non-diabetic rats significantly increased MFN2 expression compared to CTL $(P<0.001)$, ET $(P=0.003)$, and ERRI $(P=0.012)$ (Fig. 2). The combination of ERR $\alpha$ inhibition+ET in diabetic rats significantly increased MFN2 expression compared to $\mathrm{D}(P<0.001)$ and diabetic + ET groups $(P=0.012)$. ET and ERR $\alpha$ inhibition in non-diabetic and diabetic rats increased MFN2 expression compared to nondiabetic and D groups $(P<0.05)$ (Fig. 2).

The combination of ERR $\alpha$ inhibition+ET in non-diabetic rats significantly increased GLUT2 expression compared to CTL $(P<0.001)$ and ET $(P=0.01)$. The combination of ERR $\alpha$ inhibition+ET in diabetic rats significantly increased GLUT2 expression compared to D and D+ET $(P<0.001)$, and D+ ERRI $(P=0.01)$ (Fig. 3).

Our results showed that ET significantly increased $P P A R \delta$ gene expression compared to the CTL groups (non-diabetic and D controls) $(P=0.001)$ (Fig. 4). D+ET increased PPAR $\delta$ ex-

Primers sequence which used in for real-time PCR gene expression measurement

\begin{tabular}{l|l|r}
\hline \multicolumn{1}{c|}{ Gene } & \multicolumn{1}{c}{ Forward Sequence } & \multicolumn{1}{c}{ Reverse Sequence } \\
\hline MFN1 & TGGGGAGGTGCTGTCTCGGA & ACCAATCCCGCTGGGGAGGA \\
$M F N$ & AGCGTCCTCTCCCTCTGACA & TTCCACACCACTCCTCCGAC \\
GLUT2 & TAGTCAGATTGCTGGCCTCAGCTT & TTGCCCTGACTTCCTCTTCCAACT \\
$P P A R \delta$ & GCCGCCCTACAACGAGATCA & CCACCAGCAGTCCGTCTTTGT \\
$S C D 1$ & AAAGTTTCTAAGGCCGCTG & GTCTGAGCCAGCAATCTCAA \\
$18 S$ & GCAATTATTCCCCATGAACG & GGCCTCACTAAACCATCCAA \\
\hline
\end{tabular}




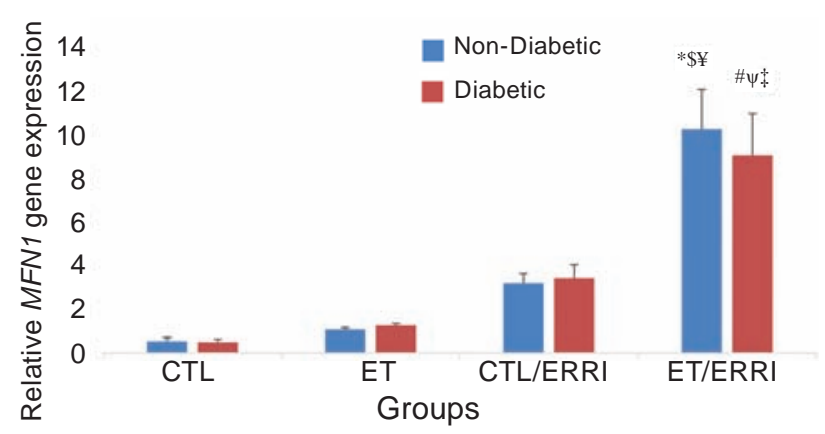

Fig 1. Relative MFN1 gene expression quantified by Real-Time PCR method in liver of studied groups. *Statistically significant to non-diabetic group, ${ }^{*}$ sta-

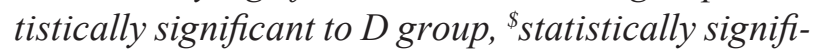
cant to ET in healthy rats, ${ }^{*}$ statistically significant to CTL +ERRI (Healthy animals which ERRa was inhibited), ${ }^{\psi}$ statistically significant to ET in diabetic rats, ${ }^{\text {}}$ statistically significant to $D+E R R I$. Data are expressed as Mean \pm SEM. $(P<0.05$ was considered as significant).

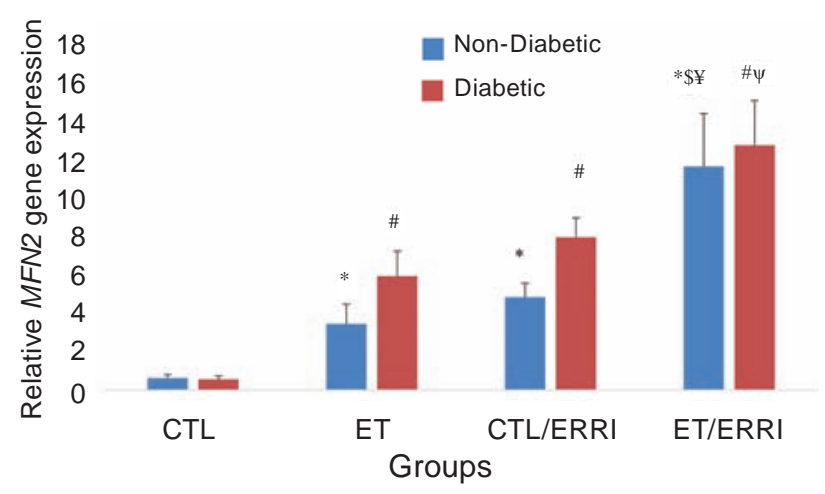

Fig 2. Relative MFN2 gene expression quantified by Real-Time PCR method in liver of studied groups. *Statistically significant to CTL group, " cally significant to D group, ${ }^{\$}$ statistically significant to ET rats, ${ }^{*}$ statistically significant to $C T L+E R R I$, ${ }^{\psi}$ statistically significant to $D+E T$, Data are expressed as Mean \pm SEM. $(P<0.05$ was considered as significant).

pression compared to D+ERRI $(P=0.002)$ and D+ET+ERRI $(P=0.061)$ (Fig. 4).

In D+ERRI group the SCD1 expression significantly increased compared to the DM and D+ET $(P<0.001)$, and D+ERRI+ET group $(P=0.001)$ (Fig. 5). The ERR $\alpha$ inhibition and the combination of ERR $\alpha$ inhibition+ET significantly increased SCD1 expression compared to CTL and ET groups $(P<0.001)$ (Fig. 5).

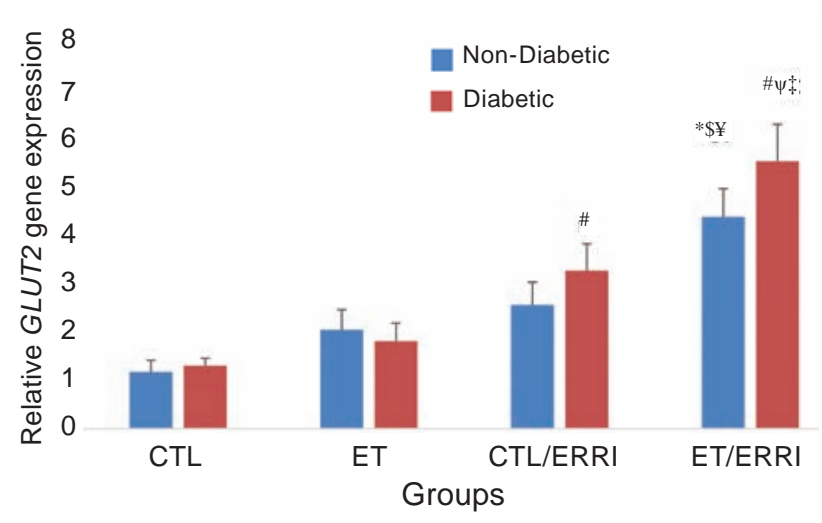

Fig 3. Relative GLUT2 gene expression quantified by Real-Time PCR method in liver of studied groups. *Statistically significant to CTL group, " statistically significant to D group, ${ }^{\$}$ statistically significant to ET rats, ${ }^{*}$ statistically significant to $C T L+E R R I$, "statistically significant to ET in D rats, " ${ }^{*}$ statistically significant to $D+E R R I$. Data are expressed as Mean \pm SEM. $(P<0.05$ was considered as significant)

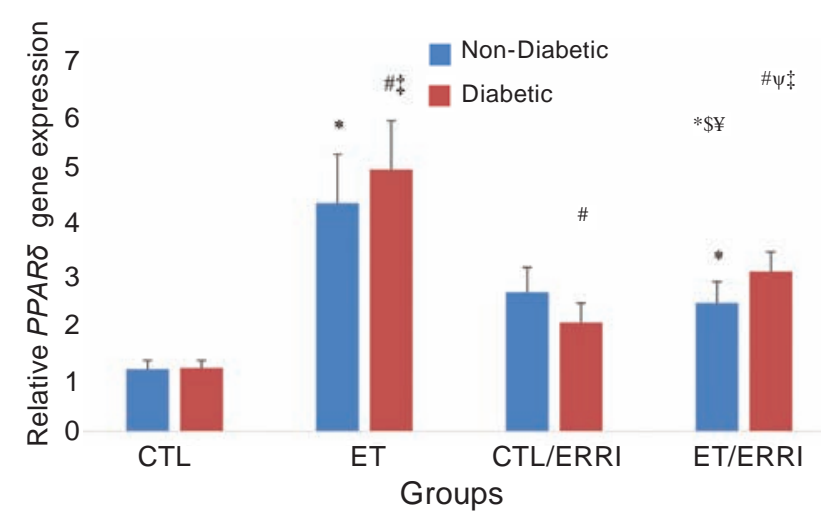

Fig 4. Relative PPAR gene expression quantified by Real-Time PCR method in liver of studied groups. *Statistically significant to CTL group, "statistically significant to D group, ${ }^{*}$ statistically significant to D+ERRI. Data are expressed as Mean \pm SEM. $(P<0.05$ was considered as significant $)$

In the current study, we examined the ET and ERR $\alpha$ inhibition effects alone and in combination on the expression of genes involved in mitochondrial fusion and other genes that regulate lipid metabolism in non-diabetic and diabetic rats. Our results showed that ET significantly increased MFN2 and PPAR $\delta$ expression in healthy and diabetic rats. ERR $\alpha$ inhibition in health and diabetic rats significantly promoted MFN2 and SCD1 expression. Finally, we 


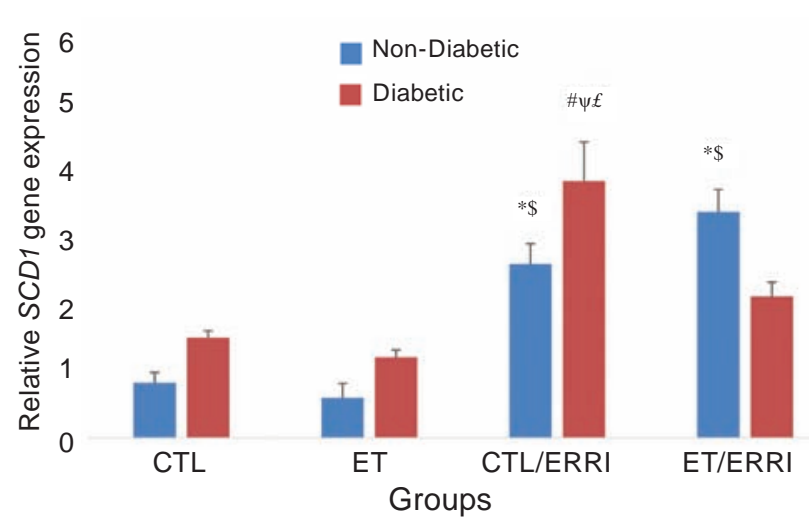

Fig 5. Relative SCD1 gene expression quantified by Real-Time PCR method in liver of studied groups. *Statistically significant to CTL group, " significant to D group, ${ }^{\$}$ statistically significant to ET in rats, ${ }^{\psi}$ statistically significant to ET in DM rats, ${ }^{s}$ statistically significant to $D+E T+E R R I$. Data are expressed as Mean \pm SEM. $(P<0.05$ was considered as significant)

found that a combination of ERR $\alpha$ inhibition with ET increased MFN1, MFN2 and GLUT2 expression.

ET is documented as a good alternative for diabetes management. ET elevated mitochondrial size and content and therefore promotes the oxidative capacity and reduces insulin resistance [4]. The proteins MFN1 and MFN2 are involved in mitochondrial dynamic [17]. It has been reported that downregulated MFN2 activity and function in rat liver were correlated with metabolic disorder including diabetes and insulin resistance. Also, in patients with diabetes, MFN2 expression was reduced [18, 19]. Exercise is considered as an important factor that decreased mitochondrial imbalance and, Koo and Kong (2019) found that exercise on treadmill increased fusion proteins such as OPA1, MFN1 and MFN2 in the brain [20]. Soriano and colleagues have reported that improved insulin sensitivity after exercise training was related to MFN2 up-regulation [19]. Our results showed that ET significantly increased only MFN2, but not MFN1 expression in the liver of non-diabetic and diabetic rats that are the same with earlier studies, considering MFN2 and its beneficial effects in diabetes.

ERR $\alpha$ regulates glucose and lipid metabolism [9]. It has been reported that ERR $\alpha$ up-regulates MFN2 gene expression [19]. Cartoni and coworkers showed that MFN2 expression is dependent on PGC$1 \alpha / \mathrm{ERR} \alpha$ and MFN2 is up-regulated by ERR $\alpha$ [4]. Unlike this, we found significant up-regulation of
MFN2 (MFN1 was increased but this was not significant) in ERRI group. This MFN2 up-regulation in the presence of ERR $\alpha$ inhibition probably is dependent on its other roles rather than involving in mitochondrial fusion. But, the mechanism of this elevation is not clear. As well as, the group that has a combination of ET and ERR $\alpha$ inhibition, showed a significant increase in both MFN1 and MFN2 expression. We observed an additive effect between ET and ERR $\alpha$ inhibition to up-regulate MFN1 and MFN2 expression. These results also confirmed that MFN2 probably is more important in mitochondrial dynamic and function after ET, ERR $\alpha$ inhibition, and a combination of both.

GLUT2 facilitate glucose transportation into hepatocytes [10]. GLUT2 expression in diabetes was evaluated in several studies but the results were challenging [10-16]. In the current study, there was no significant difference over GLUT2 expression in non-diabetic and diabetic rats. It was reported that GLUT2 expression was increased in diabetic rats [10]. Sandoval-Muníz and colleagues (2018) showed that GLUT2 gene expression was increased in diabetic rats compared to the CTL group [14]. It has been reported that GLUT2 expression was increased in liver tissue of diabetic rats [16]. In fact, in our study GLUT2 expression showed a slight elevation in diabetic rats, and also in rats that performed ET (non-diabetic and diabetic), but these changes were not significant. On the other hand, Rathinam and Pari found that GLUT2 expression in the liver was reduced in STZ-induced diabetic rats [13]. Also, GLUT2 gene and protein expression decreased in diabetic mice and rats and this reduction was related to glucose-stimulated insulin secretion [11, 12]. Our data are totally opposite in comparison with the studies that showed reduced GLUT2 expression. Disturbed glucose-induced insulin secretion correlated with GLUT2 down-regulation, and in diabetic models, increased Non-esterified fatty acid (NEFA) repress GLUT2 expression. But, it seems that because of tissue-specific regulation of GLUT2, it must reduce in pancreatic beta-cells but not in liver and this can justify our finding that we did not find any significant differences of GLUT 2 expressions in non-diabetic and diabetic rats in controls and ET groups [12]. ERR $\alpha$ inhibition in diabetic rats increased GLUT 2 expression, also a combination of ERR $\alpha$ inhibition plus ET up-regulated GLUT2 expression in both non-diabetic and diabetic rats. ET alone did not show significant effects on GLUT 2 
expression, but in combination with ERR $\alpha$ inhibition, we found an additive effect of ET and ERR $\alpha$ inhibition on GLUT 2 expression in liver. ERR $\alpha$ null mice showed reduced blood glucose levels, and this GLUT2 up-regulation especially in diabetic rats can explain this phenomenon, and also confirm its beneficial effects in diabetic rats especially in combination with ET [9].

PPAR $\delta$ modulates energy consumption in peripheral tissues and liver. Also, it improves insulin resistance, glucose homeostasis, and FAO [22, 23]. $\operatorname{PPAR} \delta$ expression was increased only after ET, but its changes were not significant in other groups. The change in substrates expenditure from glucose into FA is a marker of physical activity effects. Fan and coworkers found that PPAR $\delta$ is related to ET in mice and PPAR $\delta$ elevation significantly reduced glucose oxidation [25]. Our data are along with previous studies, and ET is related to PPAR $\delta$ expression in non-diabetic and diabetic rats. Shortly, PPAR $\delta$ agonist showed exercise mimetic effects, and this also confirmed our data that ET partially exerts its effects through PPAR $\delta$ augmentation [25]. ERR $\alpha$ inhibition has no effect on PPAR $\delta$ expression and also ERR $\alpha$ inhibition neutralized ET effect on PPAR $\delta$ expression in groups that performed ET and ERR $\alpha$ was inhibited. ERR $\alpha$ increase FAO and mitochondrial oxidative phosphorylation and its inhibition significantly reduced $\operatorname{PPAR} \delta$ expression in diabetic rats. ET increased PPAR $\delta$ expression but our results showing that in group of ERRI+ET, PPAR $\delta$ expression we reduced. Therefore, probably ET effects on PPAR $\delta$ exerted by ERR $\alpha$ and this effect was blocked by ERR $\alpha$ inhibition in ERRI+ET group.

Stearoyl CoA Desaturase 1 (SCD1) control and regulate monounsaturated FAs synthesis. SCD1 also is important for the production, storage, and move- ments of TG. SCD activity increased in diabetes and is correlated to obesity and cardiovascular disease (CVD) [26]. Our data also showed that SCD1 expression increased in diabetic rats compared to the health control group. Also, we found that ET has no significant effects on SCD1 expression in diabetic and nondiabetic rats. Shen et al found that SCD1 expression was increased after high-fat diet but not by exercise training [27] which was along with our results. Also, Yasari and colleagues reported that exercise training (8-week) attenuated SCD1 protein and gene expression in the liver [28]. ERR $\alpha$ inhibition (non-diabetic and diabetic group) increased SCD1 expression compared to control and ET counterparts. But, ET + ERR $\alpha$ inhibition significantly reduced SCD1 expression in diabetic rats that indicating ET blocks ERR $\alpha$ inhibition effects on SCD1 expression.

Conclusion. Considering the PPAR $\delta$ expression pattern in this study, it seems that ERR $\alpha$ inhibition is not a good intervention in diabetic models because it undoes ET promoting effects on PPAR $\delta$ expression. On the other hand, ERR $\alpha$ inhibition+ET increased MFN1 and especially MFN2 expression that indicates that it improve mitochondrial dynamic and function in the liver. ERR $\alpha$ inhibition+ET also increased GLUT2 expression in diabetic rats that helps to reduce blood glucose levels. It is necessary to focus on ERR $\alpha$ effects in diabetes to discover other aspects of this intervention's in diabetic models.

Conflict of interest. Authors have completed the Unified Conflicts of Interest form at http:/ukrbiochemjournal.org/wp-content/uploads/2018/12/ coi_disclosure.pdf and declare no conflict of interest.

Funding. This study was funded by Kerman Medical University Research Council. 


\section{ВПЛИВ ФІЗИЧНИХ ТРЕНУВАНЬ ТА ІНГІБУВАННЯ ЕСТРОГЕННОГО РЕЦЕПТОРА АЛЬФА НА ЕКСПРЕСІЮ МІТОФУЗИНУ 1 I 2 , GLUT2, PPARß/ס I SCD1 У ПЕЧІНЦI ДІАБЕТИЧНИХ ЩУРІВ}

\section{B. Shahouzehi', ${ }^{1,2}$, Y. Masoumi-Ardakani ${ }^{3}$, H. Fallah ${ }^{4}$, S. Aminizadeh ${ }^{3 凶}$}

${ }^{1}$ Student Research Committee, School of Medicine, Kerman University of Medical Sciences, Kerman, Iran;

${ }^{2}$ Cardiovascular Research Center, Institute of Basic and Clinical Physiology Sciences, Kerman University of Medical Sciences, Kerman, Iran; ${ }^{3}$ Physiology Research Center, Institute of Basic and Clinical Physiology Sciences, Kerman University of Medical Sciences, Kerman, Iran; ${ }^{4}$ Department of Biochemistry, Afzalipour School of Medicine, Kerman University of Medical Sciences, Kerman, Iran; e-mail: soheilaminizadeh@gmail.com

Діабет - прогресуюче метаболічне захворювання, широко поширене у всьому світі. Фізична активність вважається одним із засобів для поліпшення стану за діабету. Одним із нових підходів до лікування цукрового діабету $\epsilon$ інгібування естрогензв'язаного рецептора $\alpha$ $(E R R \alpha)$. У роботі вивчали вплив одночасного інгібування ERR $\alpha$ та фізичного тренування на експресію генів мітофузину 1 (MFN1), MFN2, транспортеру глюкози 2 (GLUT2), $\beta$ - i $\delta$-рецепторів, що активуються пероксисомними проліфераторами (PPAR $\beta / \delta)$ і стеароїл-КоАдесатурази 1 (SCD1) в печінці щурів. Щурів було розділено на 8 груп $(n=7): 1$ - контроль (CTL); 2 - діабетичні щури (D); 3 - інгібування ERR (ERRI); 4 - тренування на витривалість (ET); 5 діабетичні щури + інгібування ERR (D+ERRI); 6 - діабетичні щури + тренування на витривалість (D+ET); 7 - тренування на витривалість + інгібування ERR (ET+ERRI); 8 - діабетичні щури + тренування на витривалість + інгібування ERR (D+ET+ERRI). Тканини печінки використовували для ПЛР-тесту в реальному часі. Показано, що фізичне навантаження значно підвищувало експресію PPAR $\delta$, MFN1 та MFN2 в контрольних щурів порівняно 3 групою D. У групі ERRI експресія генів SCD1, GLUT2, MFN1 та MFN2 підвищувалась порівняно 3 групою CTL та D. У щурів груп CTL та D одночасне застосування інгібування ERR $\alpha$ та фізичного навантаження істотно збільшувало експресію MFN1, MFN2 та GLUT2. Дійшли висновку, що поєднання фізичних тренувань та інгібування $\mathrm{ERR} \alpha$, можна розглядати як потенційний терапевтичний метод для лікування метаболічних захворювань, зокрема діабету та серцево-судинних захворювань.

К л юч о в і с лов а: діабет, естрогенний рецептор $\alpha(E R R \alpha)$, транспортер глюкози, мітофузин, рецептори, що активуються пероксисомними проліфераторами (PPAR $\beta / \delta)$, стеароїлКоА-десатураза (SCD1).

\section{References}

1. Thent ZC, Das S, Henry LJ. Role of exercise in the management of diabetes mellitus: the global scenario. PLoS One. 2013; 8(11): e80436.

2. Roden M. Exercise in type 2 diabetes: to resist or to endure? Diabetologia. 2012; 55(5): 1235-1239.

3. Rezaei S, Molanouri Shamsi M, Mahdavi M, Jamali A, Prestes J, Tibana RA, Navalta JW, Voltarelli FA. Endurance exercise training decreased serum levels of surfactant protein D and improved aerobic fitness of obese women with type-2 diabetes. Diabetol Metab Syndr. 2017; 9: 74.

4. Cartoni R, Léger B, Hock MB, Praz M, Crettenand A, Pich S, Ziltener JL, Luthi F, Dériaz O, Zorzano A, Gobelet C, Kralli A, Russell AP. Mitofusins 1/2 and ERRalpha expression are increased in human skeletal muscle after physical exercise. J Physiol. 2005; 567(Pt 1): 349-358.

5. Russell AP, Feilchenfeldt J, Schreiber S, Praz M, Crettenand A, Gobelet C, Meier CA, Bell DR. Endurance training in humans leads to fiber type-specific increases in levels of peroxisome proliferator-activated receptor- $\gamma$ coactivator-1 and peroxisome proliferator-activated receptor- $\alpha$ in skeletal muscle. Diabetes. 2003; 52(12): 2874-2881.

6. Cheng S, Kujala UM. Exercise in type 2 diabetes: The mechanisms of resistance and endurance training. J Sport Health Sci. 2012; 1(2): 65-66.

7. Ishihara N, Eura Y, Mihar K. Mitofusin 1 and 2 play distinct roles in mitochondrial fusion reactions via GTPase activity. J Cell Sci. 2004; 117(Pt 26): 6535-6546. 
8. Eskiocak B, Ali A, White MA. The estrogenrelated receptor $\alpha$ inverse agonist XCT 790 is a nanomolar mitochondrial uncoupler. Biochemistry. 2014; 53(29): 4839-4846.

9. Audet-Walsh É, Giguére V. The multiple universes of estrogen-related receptor $\alpha$ and $\gamma$ in metabolic control and related diseases. Acta Pharmacol Sin. 2015; 36(1): 51-61.

10. Burcelin R, Eddouks M, Kande J, Assan R, Girard J. Evidence that GLUT-2 mRNA and protein concentrations are decreased by hyperinsulinaemia and increased by hyperglycaemia in liver of diabetic rats. Biochem J. 1992; 288(Pt 2): 675-679.

11. Burkhardt BR, Parker MJ, Zhang YC, Song S, Wasserfall $\mathrm{CH}$, Atkinson MA. Glucose transporter-2 (GLUT2) promoter mediated transgenic insulin production reduces hyperglycemia in diabetic mice. FEBS Lett. 2005; 579(25): 5759-5764.

12. Thorens B. GLUT2, glucose sensing and glucose homeostasis. Diabetologia. 201;58(2):221-232.

13. Rathinam A, Pari L. Myrtenal ameliorates hyperglycemia by enhancing GLUT2 through Akt in the skeletal muscle and liver of diabetic rats. Chem Biol Interact. 2016; 256: 161-166.

14. Sandoval-Muníz RJ, Vargas-Guerrero B, Guzmán TJ, García-López PM, MartínezAyala AL, Domínguez-Rosales JA, GurrolaDíaz CM. Lupin gamma conglutin protein: effect on Slc2a2, Gck and Pdx-1 gene expression and GLUT2 levels in diabetic rats. Rev Bras Farmacog. 2018; 28(6): 716-723.

15. Rencurel F, Waeber G, Antoine B, Rocchiccioli F, Maulard P, Girard J, Leturque A. Requirement of glucose metabolism for regulation of glucose transporter type 2 (GLUT2) gene expression in liver. Biochem J. 1996; 314(Pt 3): 903-909.

16. Jurysta C, Nicaise C, Giroix MH, Cetik S, Malaisse WJ, Sener A. Comparison of GLUT1, GLUT2, GLUT4 and SGLT1 mRNA expression in the salivary glands and six other organs of control, streptozotocin-induced and GotoKakizaki diabetic rats. Cell Physiol Biochem. 2013; 31(1): 37-43.

17. Xue R, Yang J, Jia L, Zhu X, Wu J, Zhu Y, Meng Q. Mitofusin2, as a protective target in the liver, controls the balance of apoptosis and autophagy in acute-on-chronic liver failure. Front Pharmacol. 2019; 10: 601.

18. Kawalec M, Beręsewicz M, Zabłocki K, Zabłocka B. Mitofusin 2 and mitochondrial dynamics in norm and pathology. Postepy Biochem. 2016; 62(2): 149-157.

19. Soriano FX, Liesa M, Bach D, Chan DC, Palacin M, Zorzano A. Evidence for a Mitochondrial Regulatory Pathway Defined by Peroxisome Proliferator-Activated Receptor- $\gamma$ Coactivator$1 \alpha$, Estrogen-Related Receptor- $\alpha$, and Mitofusin 2. Diabetes. 2006; 55(6): 1783-1791.

20. Koo JH, Kang EB. Effects of treadmill exercise on the regulatory mechanisms of mitochondrial dynamics and oxidative stress in the brains of high-fat diet fed rats. J Exerc Nutrition Biochem. 2019; 23(1): 28-35.

21. Luquet S, Gaude C, Holst D, Lopez-Sorian J, JehlPietri C, Fredenrich A, Grimaldi PA. Roles of PPAR delta in lipid absorption and metabolism: a new target for the treatment of type 2 diabetes. Biochim Biophys Acta. 2005; 1740(2): 313-317.

22. Liu Y, Colby JK, Zuo X, Jaoude J, Wei D, Shureiqi I. The role of PPAR- $\delta$ in metabolism, inflammation, and cancer: many characters of a critical transcription factor. Int J Mol Sci. 2018; 19(11): 3339.

23. Qin X, Xie X, Fan Y, Tian J, Guan Y, Wang X, Zhu Y, Wang N. Peroxisome proliferatoractivated receptor-delta induces insulin-induced gene-1 and suppresses hepatic lipogenesis in obese diabetic mice. Hepatology. 2008; 48(2): 432-441.

24. Cheang WS, Wong WT, Zhao L, Xu J, Wang L, Lau CW, Chen ZY, Ma RC, Xu A, Wang N, Tian XY, Huang Y. PPAR $\delta$ is required for exercise to attenuate endoplasmic reticulum stress and endothelial dysfunction in diabetic mice. Diabetes. 2017; 66(2): 519-528.

25. Fan W, Waizenegger W, Lin CS, Sorrentino V, He MX, Wall CE, Li H, Liddle C, Yu RT, Atkins AR, Auwerx J, Downes M, Evans RM. PPAR $\delta$ promotes running endurance by preserving glucose. Cell Metab. 2017; 25(5): 1186-1193.e4.

26. Steffensen KR, Gustafsson JA. Putative metabolic effects of the liver X receptor (LXR). Diabetes. 2004; 53(Suppl 1): S36-S42.

27. Shen Y, Xu X, Yue K, Xu G. Effect of different exercise protocols on metabolic profiles and fatty acid metabolism in skeletal muscle in highfat diet-fed rats. Obesity (Silver Spring). 2015; 23(5): 1000-1006.

28. Yasari S, Prud'homme D, Wang D, Jankowski M, Levy E, Gutkowska J, Lavoie JM. Exercise training decreases hepatic SCD-1 gene 
expression and protein content in rats. Mol Cell Biochem. 2010; 335(1-2): 291-299.

29. Ochiai M, Matsuo T. Increased stearoyl-CoA desaturase index and triglyceride content in the liver of rats after a single bout of swimming exercise. Biosci Biotechnol Biochem. 2012; 76(7): 1350-1355.

30. Gutiérrez-Juárez R, Pocai A, Mulas C, Ono H, Bhanot S, Monia BP, Rossetti L. Critical role of stearoyl-CoA desaturase-1 (SCD1) in the onset of diet-induced hepatic insulin resistance. $J$ Clin Invest. 2006; 116(6): 1686-1695.

31. Miyazaki M, Flowers MT, Sampath H, Chu K, Otzelberger C, Liu X, Ntambi JM. Hepatic stearoyl-CoA desaturase-1 deficiency protects mice from carbohydrate-induced adiposity and hepatic steatosis. Cell Metab. 2007; 6(6): 484496.
32. Hu JZ, Long H, Wu TD, Zhou Y, Lu HB. The effect of estrogen-related receptor $\alpha$ on the regulation of angiogenesis after spinal cord injury. Neuroscience. 2015; 290: 570-580.

33. Aminizadeh S, Masoumi-Ardakani Y, Shahouzehi B. The effects of PDK4 inhibition on AMPK protein levels and PGC-1 $\alpha$ gene expression following endurance training in skeletal muscle of Wistar rats. Ukr Biochem $J$. 2018; 90(6): 89-96.

34. Mohammadi A, Fallah H, Shahouzehi B, Najafipour H. miR-33 inhibition attenuates the effect of liver X receptor agonist T0901317 on expression of liver $\mathrm{X}$ receptor alpha in mice liver. ARYA Atheroscler. 2017; 13(6): 257-263. 